\title{
The Relationship Between Board Size and CEO Duality and Firm Performance: Evidence from Jordan
}

\author{
Almontaser Abdallah Mohammad Qadorah, Faudziah Hanim Bt Fadzil \\ Othman Yeop Abdullah Graduate School of Business, Universiti Utara Malaysia, Sintok, Malaysia \\ Email address: \\ nasr.uum@gmail.com (A. A. M. Qadorah)
}

\section{To cite this article:}

Almontaser Abdallah Mohammad Qadorah, Faudziah Hanim Bt Fadzi. The Relationship Between Board Size and CEO Duality and Firm Performance: Evidence from Jordan. International Journal of Accounting, Finance and Risk Management. Vol. 3, No. 3, 2018 , pp. 16-20. doi: 10.11648/j.ijafrm.20180303.11

Received: September 16, 2018; Accepted: October 12, 2018; Published: November 7, 2018

\begin{abstract}
This study investigates the relationship between board of directors' characteristics namely (board size and CEO duality) and firm performance among Jordanian listed firms. Firm performance is measured using return on assets (ROA). Due to limited studies regarding corporate governance practices and firm performance has been done in developing countries like Jordan. Importantly, these studies have also been limited in their scope due to restricted and particularized focus on factors hindering firm performance in the industrial sector of Jordan. This study covers industrial listed firms on the Amman Stock Exchange, Jordan for the year 2013 as a sample. Multiple regression analysis is used to test the hypotheses and to examine the relationship between board of directors' characteristics namely (board size and CEO duality) and firm performance. The findings showed that board size is significantly and positively related to ROA. On the other hand, CEO duality is significantly and negatively related to ROA. These results indicate that corporate governance plays a vital role in enhancing firm performance and reducing agency conflict. Further, regulator bodies in Jordan should increase the effectiveness of corporate governance in industrial Jordanian firms in order to enhance the quality of financial reports. In addition, this study opens up avenues for more studies on firm performance not only in Jordan, but also in other countries where this area of study is lacking.
\end{abstract}

Keywords: Corporate Governance, Board of Directors Size, CEO Duality, Firm Financial Performance

\section{Introduction}

The most Arab studies were concentrated at local and regional level regarding current corporate governance approaches accountability and only discuss governance structure of corporate system design of companies. However, few researchers have conducted that addressed corporate governance approaches effect on financial reporting of firm, thus it was stressed that thorough studies regarding the mechanisms that affect firm financial performance should be conducted. Therefore, the Jordanian government issued the Corporate Governance Code in 2009 by Amman Stock Exchange (ASE), and Jordanian companies have to observe requirements of the governance code since 2009 [1]. However, the World Bank (2004) and International Monetary Fund (IMF) had assessed corporate governance conditions in Jordan. They determined Jordanian firms are not properly followed the corporate governance rules and regulations. The Companies are following very initial stage of code of corporate governance in Jordan. This can be ascribed by operational performance of board of directors' and weak independency of their members [2, 3].

Moreover, the purpose of this study is to check the effect of both board of director size and CEO duality on the financial activities of listed firms in Jordon. Preceding empirical studies at both developed and developing areas have been considered to support the relationship between corporate governance and a firm's financial performance. Prior work indicated that there are some measurements for corporate governance such as: (i) board size; and (ii) CEO duality. Besides, return on asset (ROA) ratio is a measurement tool for firm financial performance.

This is study has scrutinized various research hypothesis which relied on a 64 listed firms on Amman Stock Exchange (ASE) during year 2013 as a sample. The analysis of the data was conducted in three stages. First, descriptive statistics was used in describing the data using minimum, maximum, mean and standard deviation. Second, correlation analysis was also 
conducted to recognize the direction of correlation between both dependent and independent variables. Lastly, Linear Regression Analysis was conducted for testing the hypotheses.

\section{Literature Review and Hypotheses}

Many previous studies have sought about the relationship between corporate governance and firm's performance. Mostly studies nominated the most significant characteristics of corporate governance for this relationship included: (i) board of director's size; and (ii) CEO duality. Below as a brief overview of these characteristics.

The BOD size is calculated by the directors' quantity in firm which is a crucial indicator for its effectiveness. Increase in the size of the BOD will likely enhance to BOD's effectiveness in offering adequate support in reducing agency cost that results from inefficient management of the firm which will eventually improve the financial results of the [4]. Kyereboah-Coleman and Biekpe argued that the larger BOD size increases firm's financial performance [5]. The possible explanation that the BOD may compose of members which are more expert and capable to undertake vital decisions, and will be harder for a powerful CEO to control the decisions of the BOD. The outcome could improve governance, more especially improve efficiency of firm's management and enhance its financial performance. The argument has been made by Dalton and Dalton that apart from getting networking opportunities and access to business resources, larger boards could benefit the company through advice and counsel [6]. The diversity of the BOD can also be ensured through the enlargement of the BOD's so that the BOD can be composed of varieties of members with experience, skill sets, gender, and race.

Contrarily, it was argued by Jensen that BOD's with larger composition will likely be ineffective due to the possibility of difficulty for CEO to regulate the activities of the BOD [7]. He further argued that if the BOD gets too big, the difficulty in coordinating it activities will increase and this might cause problems. The smaller BOD's is that reduces the possible occurrence of unrestricted riding by single director and increases their participation for making decisions. Thus, Salihi opined that assistances could possibly drive from efficient management control through large board size [8]. This can be counterbalance by the future problems relating direction, statement, and policymaking. The statement of Salihi was further sustained by Nath, Islam and Saha they emphasized that board size reduction represents the firm financial performance $[8,9]$.

Gill and Mathur argue larger size is negatively related to firms' financial performance [10]. Kouki and Guizani considered the degree of BOD efficiency in supervising the function of the board of directors and reducing firm financial performance [11]. The result showed the positive influence of firm financial performance on board size. They further suggest higher boards are inefficient in supervising duties than lesser boards. Conyon suggest an inverse relationship [12]. Kumar and Singh suggest firm with larger board size have a lower variability of corporate value, and as such board sizes are negatively related to firm financial performance [13]. Thus, inconsistent findings have been documented in the board size impact on firm financial performance measures of firms. Hence, the first hypothesis is as follows:

$H_{1}$ : There is a positive relationship between BOD size and firm financial performance.

Separation of CEO from Chairman of the board's duties offers a separate leadership structure. According to Yusoff and Alhaji CEO will be more powerful in optimizing his benefit at the expense of the shareholders if the same person is performing the role of CEO and board chairman than likelihood of other people to control his own power is more apparent [14]. The separation of leadership composition is preferred in order to control the CEO impartially and efficiently. Nonetheless, the point when the same individual stands the twofold "control" of a board Chairman and CEO, leading of the board is generally proclaimed, the chairman is persuaded towards the management interest rather than shareholders' interest [15].

In their work, Kyereboah-Coleman and Biekpe investigate the influence of CEO duality and firm financial performance through ROA, Tobin's Q and sales Growth of listed firms on Ghana Stock Exchange. Their finding revealed that there should be separate persons for chairman and CEO designation which reduces anticipated conflict between managers and board members, thus it shows a positive effect on performance of non-financial firms in Ghana [5].

In their study, Kalsie and Mittal Shrivastav contend that the governance of a board is greatly compromised if incumbent CEO who also assist as board chairman [16]. The implication from this is that it is the same person that will frequently set the agenda for the board and still control the issues brought during the meetings of the board. Additionally, where CEO serve as chairman of the board, she/he may influence nomination and appointment of applicants against board seats, which eventually, increase possibility that novel board hired persons must dependent on administration despite that they are "outsiders", hence lacking independence of the board. Furthermore, the main roles of the board are to decide who will be appointed as CEO. Hence, if there is double role of CEO and chairman, which will not make an effective board decision in replacing poorly performing managers. This is for the fact that the poor performance of those managers may be linked to their connivance with the CEO. Therefore, the second hypothesis is as follows:

$\mathrm{H}_{2}$ : There is a negative relationship between $\mathrm{CEO}$ duality and firm financial performance.

\section{Measurement of Variables}

This study used the variables for empirical results including: (1) firm's financial performance as dependent variable; (2) Board size and CEO duality as independent variables. Table below shows the measurements of dependent and independent variables. 
Table 1. Measurements of Variables.

\begin{tabular}{lll}
\hline Variables & Definition & Measurement \\
\hline Dependent variable ROA & Return on asset & Earnings (before tax) divided by total assets of the firm \\
Independent variables Board size & Board of Director's Size & Number of inside and outside directors on the board \\
Duality & CEO duality & Coded "1" if Chairman also holds the position of CEO and " 0 " otherwise \\
\hline
\end{tabular}

\section{Sample of Data}

Population for this study consisted of Amman Stock Exchange (ASE) listed industrial firms, which are divided into 10 sub-sectors and comprised of 64 firms. Secondary data using annual report was utilized for the purpose of the study for the industrial firms listed on ASE for the year 2013.
The selection of 64 firms as a sample in this study is expected to give clear and comprehensive result. Furthermore, these listed companies would provide information about compliance with the code of corporate governance (CCG). It is anticipated that these companies have upright practices of corporate governance as they are required to disclose compliance with $\mathrm{CCG}$ in their financial reporting.

Table 2. Descriptive Statistics of Variables.

\begin{tabular}{llllll}
\hline Variables & N & Minimum & Maximum & Mean & Std. Dev. \\
\hline Board Size & 64 & 4.00 & 13.00 & 7.52 & 1.96 \\
CEO duality & 64 & 0.00 & 1.00 & 0.81 & 0.39 \\
ROA & 64 & -0.29 & 0.29 & 0.02 & 0.09 \\
\hline
\end{tabular}

\section{Results}

Table 3 shows the correlations between the Board size, CEO duality and ROA as the dependent variable. From the output, it can be seen that one of the two independent variables that is BOD size (Board Size) is positively interrelated with ROA, while other one (CEO duality (CEO) is negatively correlated. From Table 3, the correlation coefficient between BOD size (Board Size) and ROA is 0.21. It displays a positive relationship between BOD size and ROA where ROA will increase as the BOD size increases.
This is consistent with the finding of Jackling and Johl, where the correlation between BOD size and ROA was positive [17]. However, BOD size and ROA are not strongly correlated because the value of correlation (0.21) is very low, indicating that it is not significant at 0.05 using the 2-tailed test. Thus, there is no significant correlation between BOD size (Board Size) and ROA.

The correlation coefficient between CEO duality and ROA is -0.20 , depicting negative $(-0.20)$ effect of CEO duality on ROA at 0.05 using 2-tailed test. This is consistent with [18, 19].

Table 3. Correlation Matrix among Variables.

\begin{tabular}{llll}
\hline Variables & ROA & Board Size & CEO duality \\
\hline ROA & 1 & & \\
Board Size & 0.21 & 1 & 1 \\
CEO duality & -0.20 & 0.13 & 1 \\
\hline
\end{tabular}

Table 4 shows the output of multiple regression models for ROA. This table showed the value of R Square and adjusted R Square for the regression model.

$$
\mathrm{ROA}=\alpha 0+\beta 1 \mathrm{SIZE}+\beta 2 \mathrm{CEO}+\varepsilon
$$

Table 4. Multiple Regressions.

\begin{tabular}{lllll}
\hline Model & R & R Square & Adjusted R Square & Std. Error of Estimates \\
\hline & .307 & .094 & .064 & .088 \\
\hline
\end{tabular}

Table 4 shows the summary of the multiple regression model with firm financial performance which ROA as the dependent variable. From the table, it showed that the value for adjusted R Square is 0.064 indicating 6.4\% strength of relationship between ROA, BOD size and CEO duality. R square statistically measure coefficient of multiple determination for multiple regression.

Table 5. ANOVA.

\begin{tabular}{llllll}
\hline Model & Sum of Squares & df. & Mean Square & F & Sig. \\
\hline Regression & .049 & 2 & .025 & 3.168 & \\
Residual & .502 & 59 & .009 & & \\
Total & .631 & 63 & & \\
\hline
\end{tabular}


Another measure to see if the model is good in predicting firm financial performance is the significance of the value of $\mathrm{F}$. Based on Table 5, the value is 0.049 . Since the value is less than 0.05 , the whole regression is said to have a good fit.

Table 6. Coefficients.

\begin{tabular}{|c|c|c|c|c|}
\hline \multirow{2}{*}{ Model } & \multicolumn{2}{|c|}{ Unstandardized Coefficients } & \multirow{2}{*}{$\mathbf{T}$} & \multirow{2}{*}{ Sig. } \\
\hline & B & Std. Error & & \\
\hline Constant & -.016 & .047 & -0.346 & .730 \\
\hline Board size & .011 & .006 & 1.910 & .061 \\
\hline CEO duality & -.053 & .028 & -1.870 & .066 \\
\hline
\end{tabular}

From the equation of firm financial performance (ROA) found in Table 6 , it is noted the BOD size increases by $1 \%$, and ROA will increase $1.1 \%$. If CEO duality increases by one ROA decrease $5.3 \%$.

In Table 6, influence of BOD characteristics on ROA is presented. The output indicates mixed results between the BOD characteristics and firm financial performance (ROA) where the BOD size on this occasion has a positive impact on firm financial performance (ROA). This outcome is similar as what has been found in other studies like [20,21].

In terms of CEO duality, the result shows that there is a significant negative relationship between CEO duality and firm financial performance measured using ROA. This finding is in line with [16]. Table 7 below present the summary of the findings from hypotheses testing.

Table 7. Summary of the Hypothesis Testing.

\begin{tabular}{lll}
\hline Number & Hypothesis & Result \\
\hline H1 & There is a positive relationship between BOD size and firm financial performance. & Supported \\
H2 & There is a negative relationship between CEO duality and firm financial performance. & Supported \\
\hline
\end{tabular}

\section{Conclusion}

The first purpose of this study is to investigate the effect of BOD size on financial performance. Attainment of objective was based on the hypothesis that "there is a positive relationship between BOD size and firm financial performance". Thus, this study has a positive relationship between BOD size and ROA. Consequently, this finding supported the hypothesis and fully achieved the objective and clearly answered the related research question. Furthermore, based on the finding, BOD size has significant effect on boosting financial performance especially at Amman Stock Exchange for industrial firms.

In line with that, the larger BOD size, the better performance can be achieved, and would provide extra board monitoring and subsequently corporate players could perform their duties effectively and efficiently in enhancing shareholders value. Therefore, higher number of BOD may increase the number of potential solution strategies, increase the range of perspectives, offer a high level of expertise, provide well networking, and be further able to monitor top management performance. It is determined that a huge number of BOD size will enhance firms' financial performance.

To investigate CEO duality effect on firm financial performance is next objective. For its fulfilment, this study hypothesized that "there is a negative relationship between CEO duality and firm financial performance". After empirically test the hypothesis, results revealed a negative relationship between the financial performance of firms and CEO duality. Hence, when one person has two important positions spontaneously; he or she will ready to make such decisions which work for own interest rather than firms' performance.

Furthermore, agency theory also proposed that there should be two different persons for two different designations. This rule can introduce efficient monitoring system. Therefore, there should be a separation between CEO and chairman persons' which provide high financial performance of firms.

These study findings will assist the future researchers to further explore the empirical importance of BOD's characteristics in Jordan. As long as the implication about Corporate Governance Code 2009 its initial stage in Jordan, the gap leads to vague explanations and requires further studies. Therefore, this study can encourage and highlights some recommendations for upcoming studies which conducted according to interest, also to overcome the limitation encountered by this study. The recommendations are highlighted as follows:

1. nclude other listed firms either the industrial firms by making use of a different method such as financial and services firms.

2. onsider other performance measurements including ROE, EPS, Tobin's Q and ROI.

3. xtend the period of using data for more than one year, through time-series or panel data analyses.

4. onsider other aspects of BOD's characteristics which are not included in recent study to further examine firm financial performance. Such variables may include remuneration and nominating committees, the board of director's frequency and board of directors' experiences. 


\section{References}

[1] Alkhatib, K., \& Eqab Al Bzour, A. (2011). Predicting corporate bankruptcy of Jordanianlisted companies: Using Altman and Kida models. International Journal of Business and Management, 6(3), p 208.

[2] Abdullatif, M., \& Al-Khadash, H. A. (2010). Putting audit approaches in context: the case of business risk audits in Jordan. International Journal of Auditing, 14(1), 1-24.

[3] Ajeela E., \& Hamdan A. (2011). The relationship between corporate governance and earnings management: Evidence from Jordan. Arab Journal of Administrative Sciences, 17(2), $1-28$.

[4] Jensen, M., \& Meckling, W. (1976). Theory of the firm: managerial behavior, agency costs and ownership structure. Financial Economics, 3(4), 305-360.

[5] Kyereboah-Coleman, A., \& Biekpe, N. (2005). The relationship between board size, board composition CEO duality and firm performance experience from Ghana. Working paper.

[6] Dalton, C. \& Dalton, D. (2005). Boards of directors: Utilizing empirical evidence in developing practical prescriptions. British Journal of management, 16(1), 91-97.

[7] Jensen, M. (1993). Modem industrial revolution, exit, and the failure of internal control systems. Journal of Finance, 3(4), 831-80.

[8] Salihi, A. A. (2015). The effect of board the size and audit committee the size on earnings management in Nigerian consumer industries companies. International Journal of Innovative Research and Development|| ISSN 2278-0211, 4(3).

[9] Nath, S. D., Islam, S., \& Saha, A. K. (2015). Corporate Board Structure and Firm Performance: The Context of Pharmaceutical Industry in Bangladesh. International Journal of Economics and Finance, 7(7), 106.

[10] Gill, A., \& Mathur, N. (2011).Board size, CEO duality, and the value of Canadian Manufacturing firms. Journal of Applied Finance and Banking, 1(3), 1-13.

[11] Kouki, M., \& Guizani, M. (2015). Outside directors and firm performance: The moderating effects of ownership and board leadership structure. International Business Research, 8(6), 104.

[12] Conyon, M. J. (2014). Executive compensation and board governance in US firms. The Economic Journal, 24(574), F60-F89.
[13] Kumar, N., \& Singh, J. P. (2013). Effect of board size and promoter ownership on firm value: some empirical findings from India. Corporate Governance: The international journal of business in society, 13(1), 88-98.

[14] Yusoff, W. F. W., \&Alhaji, I. A. (2012). Corporate governance and firm performance of listed companies in Malaysia. rends and Development in Management Studies, (1), 43-65.

[15] Liao, L. K. C., Mukherjee, T., \& Wang, W. (2015). Corporate governance and capital structure dynamics: An empirical study. Journal of Financial Research, 38(2), 169-192.

[16] Kalsie, D., \& Mittal Shrivastav, S. (2016). The Relationship between CEO Duality and Firm Performance: An Analysis Using Panel Data Approach.

[17] Jackling, B., \& Johl. S. (2009). Board Structure and Firm Performance: Evidence from India's Top Companies. Journal of Corporate Governance: An International Review, 17(4): 492-509.

[18] Ujunwa, A., Salami, P. O., \& Umar, A. H. (2013, January). CEO Duality and Firm Performance: An Integration of Institutional Perceptive with Agency Theory. In Proceedings of World Academy of Science, Engineering and Technology (No. 73, p. 860). World Academy of Science, Engineering and Technology (WASET).

[19] Fooladi, M. (2012) Board characteristics and firm performance, Journal of Modern Accounting and Auditing, 8(5):688-694.

[20] Fauzi, F., \& Locke, S. (2012). Board structure, ownership structure and firm performance: A study of New Zealand listed-firms.

[21] Nodeh, F. M., Anuar, M. A., Ramakrishnan, S., \& Raftnia, A. A. (2016). The Effect of Board Structure on Banks Financial Performance by Moderating Firm Size. Mediterranean Journal of Social Sciences, 7(1), 258.

[22] Schmid, M., Zimmerman, H. (2007), Should chairman and CEO be separated? leadership structure and firm perform Switzerland. Working paper, from $\mathrm{http}: / /$ papers.ssrn.com/sol3/papers.cfmabstract_id=696381.

[23] Saeed, M. B., Murtaza, Z., \& Sohail, I. (2013). Corporate Governance and Firm Performance: A Study on Moderating Effects of Firm Size and Leverage on the Relationship between Corporate Governance and Firm Performance in Banking Sector of Pakistan. 